\title{
Brazilian Hamlet: Essay on Linguistic Turn and Historiographical Indeterminacy (1970-1980)*
}

\author{
Temístocles Cezar \\ t.cezar@ufrgs.br \\ Associate Professor \\ Universidade Federal do Rio Grande do Sul \\ Av. Bento Gonçalves, 9500 \\ 91509-900 - Porto Alegre - RS \\ Brazil
}

\begin{abstract}
This essay aims to analyze the first developments of the linguistic turn in the Brazilian historiography. Considering the shortage of research in this field, I have chosen to make, first of all, a brief description of the emergence of the linguistic turn in general terms and, then, an analysis of some primary texts of Brazilian authors that relate, in different ways, to this theme.
\end{abstract}

\section{Keywords}

Linguistic turn; Brazilian historiography; History writing.

Received in: 2/20/2014

Approved in: 7/1/2014

\begin{abstract}
* The first version of this essay was presented the Seminário Brasileiro de História da Historiografia (Brazilian Seminar of History of Historiography - SNHH), which took place in August 2012 in the Mariana campus of UFOP, with the overall theme of "The Linguistic Turn and Historiography: Assessment and Perspectives". I would like to thank the kindness of my colleagues in the round table named "National Contexts and Linguistic Turns: Experiences of Time, Narrative and Memory", Professor Verónica Tozzi (UBA) and Professor Sérgio Campos Matos (University of Lisbon) and the comments by Estevão de Rezende Martins, Valdei Lopes de Araujo, Mateus Henrique Pereira and Sérgio da Mata. I had the opportunity to discuss the work more thoroughly in the Laboratory of Theory and Historiography at PUC-Rio in August 2013. I would also like to thank the organizers and participants of the event, in particular Marcelo Jasmin, Ricardo Benzaquen Araújo, Marcos Veneu and Henrique Estrada. I am grateful to Edgar De Decca, with whom I discussed my impressions on the subject in October 2013 during the "History Week" at Udesc. I would also like to express my gratitude to Fernando Nicolazzi, Arthur Ávila and Benito Schmidt, all of them my colleagues in the same department, and Alexandre Avelar for the careful reading, the critiques and suggestions, crucial for the final version of this text, which still aims to be, even in face of his valuable observations, an initial mapping over the theme. Finally, I would like to thank Flávia Varella and Bruno Franco Medeiros, tireless "logistical" supporters from the $6^{\text {th }}$ SNHH to the final version of the article. I thank Vitor Batalhone Junior for reading the English version of this article.
\end{abstract}


An homage to Luiz Costa Lima

"In my view, relativism is the moral equivalent of epistemological skepticism; moreover, I conceive relativism to be the basis of social tolerance, not a license to 'do as you please'" (WHITE 1987, p. 226).

\section{Specter, Relativism and Indeterminacy (I)}

In the introduction to the collection The Return of Grand Theory in the Human Sciences, published in 1985, Quentin Skinner warned us about "the threats to the fundamentals of human sciences", haunted as they were by the "specter of epistemological relativism" (SKINNER 1985, p. 1-20).

A classical evocation, acquiring its most famous rendition in Shakespeare, the specter is the metaphorical incarnation of collective or individual fears and apprehensions of a society. ${ }^{1}$ At the same time that it threatens, it raises doubts (on existence, on its intentions). Thus, Marx, a voracious reader of both ancient and modern authors, and particularly of the English playwright, conjured him for announcing a new era in his Manifesto: "A specter is haunting Europe - the specter of communism" (MARX 1848; DERRIDA 1994, p. 19-21).

After Marx, Valéry highlights another specter in his sad Europe of 1919:

Now, in a big terrace in Elsinor, extending from Basel to Cologne, near the sands of Nieuport, to the swamps of Soma, to the loams of Champagne, to the granites of Alsace - the European Hamlet looks at thousands of specters. He is, nevertheless, an intellectual Hamlet. He meditates on the life and death of truths. His ghosts are all the objects of our controversies (VALÉRY 1957, p. 993).

The concerns summed up by Skinner, on his own behalf and on behalf of others, are related to a vital unfolding for writing the history of the intellectual movement that has become known as the "linguistic turn": the ghost of relativism, the twin figure of another specter, that of skepticism, whose limits seem to surround the outskirts of irrationalism. Although at first sight it may seem a disciplinary organization, this movement is characterized by the scattering of ideas and the lack of a coordinating center unifying them. Therefore, speaking of a "movement" can only be legitimate if we have some theoretical tolerance.

If everyone claims the legacy of Ferdinand de Saussure's linguistics or Ludwig Wittgenstein's philosophy of language, although with different intensities, the linguistic turn reaches over different and multiple stages of time and space, either scholarly or not. Its impact, its effects or potentialities are not easy to measure. Each historiographical culture has made it suit its purposes, some more flexibly; others, more attached to their epistemological idiosyncrasies, less (LA CAPRA; KAPLAN 1982).

Thus, in 1967, the same year that sees Richard Rorty's The linguistic turn: essays in philosophical method, Jacques Derrida publishes De la grammatologie and L'écriture et la différence (RORTY 1967; DERRIDA 1967). The former can be

\footnotetext{
${ }^{1}$ See Chant 24 of the Odissey; SHAKESPEARE, William. Hamlet, Act I, Scene 1.
} 
located within the debate on analytical philosophy as method, being afterwards denied or lessened by Rorty; the latter two works have aroused both sympathy and rejection, although their author does not seem to have been affected (perhaps because he was highly suspicious of the very notion of authorship, seeing it more in terms of a discursive function than an identity). Whereas the work organized by the American thinker is situated within a context marked by narrativist theses affecting historiography (Arthur Danto, whose book Analytical philosophy of science is published in 1965; Louis Mink's articles "The autonomia of historical understanding", published in History and theory, in 1966, and "History and fiction as modes of comprehension", of 1970; and the one by William Dray, "On the nature and role of narrative in historiography", which also appears in History and theory, in 1971), ${ }^{2}$ the French author is concerned with a critique of Western metaphysics and its logocentric tendency, as he says.

The Anglo-American perspective would have a strong impulse in the field of historiography since 1973 with the publication of Hayden White's Metahistory, a book that became a reference in the "movement" to broaden the group of interlocutors. In addition to philosophers and literary critics, now historians are more markedly addressed (VANN 1998; ANKERSMIT 2001, p. 29). I personally see it as a mistake isolating Metahistory from Hayden White's other works. One example among others: the same year in which Metahistory comes to light, White publishes also an important essay named "The Greco-Roman Tradition", in the collection Major traditions of world civilizations, a collection directed by him since 1966. This essay received very little attention, even among Hellenists and Romanists (WHITE, 1973). This impression becomes clearer after rereading several articles by the historian, published among 1957 to 2007 and edited by Robert Doran, beginning with a text on "Collingwood and Toynbee: Transitions in English Historical Thought" up to "Guilty of History? The Longue Durée of Paul Ricœur" (WHITE 2010a), a review of Paul Ricœur's last book La mémoire, I'histoire, I'oubli.

It is an ongoing reflection on history that was instigating to some (few) historians and troublesome to (many) others. This troublesomeness seems to rest on a hasty assessment: even with his solid historical training, Hayden White was (and, to a great extent, still is) seen as an outsider in the history field as Lévi-Strauss was in the 1950s and 1960s. Accused of attacking history, they actually had other questionings and understandings on the task of the historian, which could be disturbing to dogmatists and others. ${ }^{3}$ In this sense, Koselleck points out, in his preface to the German translation of White's Tropics of discourse, that White is not interested in history as a discipline, nor in the writing of history as an exclusively literary genre; he questions historians, in an old rhetorical tradition, or, more precisely, their texts and the way they can socially mediate their intention of truth (KOSELLECK 2002, p. 38-44). ${ }^{4}$ In the words of Verónica Tozzi, White's work "is not a method for historians, but an

\footnotetext{
${ }^{2}$ For a general assessment of this reception, see the important work of Richard Vann (1995, p. 40-69).

3 On Lévi-Strauss's relationship with history, see the essay by François Hartog (2005, p. 175-189).

${ }^{4}$ This book has received a preface by Hayden White himself.
} 
alert against the naivety of language". ${ }^{5}$ From this point of view to that according to which White is nothing but an irresponsible relativist, the distance is as wide as it is thoughtless. ${ }^{6}$

The famous and tense debate between Carlo Ginzburg and Hayden White is situated within this historiographical context (GINZBURG 1992; WHITE 1992). ${ }^{7}$ Even if the response to Ginzburg is not satisfactory, since it was not a reply, it should be remarked that Hayden White has never evaded the debate on the role of irrationalism, relativism and skepticism in history (WHITE 1992, p. 37-53). Even before Metahistory was published, he anticipates future objections in "The Burden of History" (1966) and denies the condition of revisionist. ${ }^{8}$ In 1972, in a short essay named "The irrational and the problem of historical knowledge in the Enlightenment", he warned his readers about the historicity of these categories as well as their links with forms of representing the past (WHITE 1994, p. 153-167). Finally, in Metahistory, White shows that the aimed at realist historiography of the $19^{\text {th }}$ century historical thinking was characterized less by what it actually was than by what it rejected in its $18^{\text {th }}$ century forebears, that is, "what it objected to most in Enlightenment historiography was its essential irony, just as what it objected to most in its cultural reflection was its skepticism" (WHITE 1992, p. 61, italics by the author). ${ }^{9}$

On its turn, Derrida's deconstruction or rereading will impact not only on France, but also on the United States. The language that aims initially at not only invading, but also fracturing the logic of so called great narratives of social sciences, decentralizing the idea of truth as a universal value and, in its absence, or in the inexistence of a core or an origin to definitions, turning everything into discourse becomes academically and institutionally legitimate (which does not mean a lack of criticism: it suffices to invoke John Searle's 1990 devastating critique of Derrida, which has been dully responded).

However, it would be misleading to think that French scholars had made a "nationalistic" deal around the relationship between history, language, text,

\footnotetext{
${ }^{5}$ Conference presented at the $6^{\text {th }}$ Brazilian Seminar of History of Historiography - SNHH, "Linguistic Turn and Historiography: Assessment and Perspectives." See also Tozzi's introduction to White's collection of essays named Ficción histórica, historia ficcional y realidad histórica (WHITE 2010b, p. 13-29).

${ }^{6}$ The recent thesis by Herman Paul may be seen as an attempt to break with this simplistic view of White's work (PAUL 2011). Pedro Spinola Caldas, in his excellent review of H. Paul's book, highlights these aspects (CALDAS 2013, p. 277).

7 Before and after the debate in the USA, Ginzburg unilaterally developed the theme in many other texts (GINZBURG 1989, p. 178-20; 1989, p. 44-45; 1997, p. 16-24). Other authors have intermittently participated in this debate; their number does not allow us to cite them here. The already cited work by Herman Paul offers an analysis of the effects of this discussion in a subchapter of his thesis suggestively titled "Specter of Fascism" (PAUL 2011, p. 119-124). François Hartog and Francisco Murari Pires have also, more recently, discussed Ginzburg's criticism of White, even if in different perspectives (HARTOG 2011; PIRES 2013).

8 "The governing metaphor of an historical account could be treated as a heuristic rule which self-consciously eliminates certain kinds of data from consideration as evidence. The historian operating under such a conception could thus be viewed as one who, like the modern artist and scientist, seeks to exploit a certain perspective on the world that does not pretend to exhaust description or analysis of all of the data in the entire phenomenal field but rather offers itself as one way among many of disclosing certain aspects of the field. [...] The result of this attitude is not relativism but the recognition that the style chosen by the artist to represent either an inner or an outer experience carries with it, on the one hand, specific criteria for determining when a given representation is internally consistent and, on the other, provides a system of translation which allows the viewer to link the image with the thing represented on specific levels of objectification" (WHITE 1994, p. 59 , italics by the author)

${ }^{9}$ In relation to the history of skepticism, see Richard Popkin's excellent study (POPKIN 2003). For an approach more specifically directed to history, see (MUNSLOW 2010, p. 62-77).
} 
narrative or discourse. Let us look at the dates. In 1967, Roland Barthes publishes a short article called "Le disocurs de I'histoire" that quickly becomes an inescapable reference. ${ }^{10}$ In 1971, Paul Veyne publishes his Comment on écrit I'histoire: essai d'épistémologie, and Michel Foucault delivers his inaugural lecture L'ordre du discours at the Collége de France. Both are harshly criticized by another French author who also becomes known by his creative use of language of and in history, Michel de Certeau (the first in the Annales, "Une épistémologie de transition: Paul Veyne," 1972; the second in "Le noir soleil du langage par Michel Foucault", L'absent de I'histoire, 1973); still in 1973, Régine Robin publishes Histoire et linguistique, dealing mainly with methodology of markedly French discourse analysis. In 1974, Jacques LeGoff and Pierre Nora direct Faire de I'histoire, in three volumes, important for opening new analytical perspectives in which language occupies an important place, even if American narrativists are not mentioned, in particular Hayden White, who is still not translated in French, ${ }^{11}$ and almost no reference to Paul Ricœur. Finally, 1975 sees the publishing of Michel de Certeau's L'écriture de I'histoire. ${ }^{12}$ If indeed there was a third generation of the Annales - French New History - whose production would have, according to one of its hasty detractors, shredded history into pieces, it should be asked whether it is not the very notion of school that is shredded into pieces (DOSSE 1987). ${ }^{13}$

However, my objective is not so much naturalizing a chronology of the linguistic turn, as an epistemological a priori, than attempting to demonstrate that it is a construction that occurs in the 1960s and 1970s for Anglo-Saxon philosophers and literary critics, and a posteriori for many historians. There does not seem to be another reason for the success of Lawrence Stone's article, "The revival of narrative. Reflections on a new old history," published in the Past and present, in 1979.

"Narrative" here refers to another semantic field that, although it may have originated in an atmosphere wherein studies on language have some differentiated value, is sustained by a very fragile notion: "Narrative is taken to mean the organization of material in a chronologically sequential order and

\footnotetext{
${ }^{10}$ For that matter, in this article Barthes simply proposes the rubbing out of narrative! (BARTHES 1984, p. 164). This "detail" has not escaped the attention of François Hartog in a recent work (HARTOG 2013, p. 115-116).

${ }_{11}$ This does not mean that the work received no attention. For example, in volumes I and III of Temps et récit, Ricœur focuses on Hayden White's work, mainly Metahistory (RICGUR 1983, p. 286-301; 1985, p. 272-280).

${ }^{12}$ Complete references in the References section.

${ }^{13}$ In the preface to the second edition, published ten years later, in 1997, Dosse considerably relativizes his critiques (see $2^{\text {nd }}$ ed., p. I-VIII). Before him, François Furet observed that "to speak the truth, since their origin [the Annales], there is no school of thought", but hegemony in influence and reputation (FURET 1982, p. 5-9). Mixing irony and humor, in an interview he ascertains: "I always say jokingly that the Ecole des Annales has no other definition than the people I meet in the elevator by the morning. What common trait links Le Roy Ladurie, Le Goff, Richet, me etc.? How can we be put under a same umbrella term?" [Interviewed by Aspásia Camargo (CAMARGO 2003, p. 69)]. Indeed, many French scholars see no linguistic turn in France, but just a "tournant critique" resulting from two editorials published in the Annales ("Histoire et sciences sociales. Un tournant critique?", Annales, 2, mars-avril, 1988, p. 291-293; "Histoire et sciences sociales: tentons I'expérience", Annales, 6, nov-déc., 1989, p. 1317-1323). For a mapping of this movement and its differences with the linguistic turn, see the work of Gérard Noiriel. The main difference is that the French version of the turn would remain faithful to the basic presupposition of the Annales: the study of society, which seems to me a peculiarity that would need a more developed argumentation (NOIRIEL 1996, p. 150-154). In the same sense, for Christian Delacroix, the "tournant critique" may be interpreted as one of the responses of social history, which is critically loyal to the Annales, to the challenges posed by the linguistic turn (DELACROIX 2010, p. 484-485).
} 
the focusing of the content into a single, coherent story" (STONE 1974, p. 19). Its supposed return would be a consequence of disillusionment of some of the historians with economic and social history. Supported by the emergence of a history of mentalities aimed at feelings, emotions and behavioral patterns, then anthropological and, accordingly, more attentive to its ways of transmission, the narrative would be the vector of this new, other story.

I would like neither to underestimate nor to overestimate Stone's article, which, seems to me, is more important due to the debate it opens up than for its inner consistency. There were those who identified with it, those who refuted it and those who simply ignored it, but the informed historian knew about its existence. It is not surprising that the revival of narrative is followed up by so many other revivals and that our specter reemerges with great strength: relativism of new objects, new approaches, new perspectives (the Faire I'histoire triad converted into slogans of this self-titled new historiography).

In order not to make this contextualization longer, we should jump at the last considerations of historian Gabrielle Spiegel when she left the presidency of the American Historical Association, in 2009. In this lecture, suggestively titled "The task of the historian" (impossible not to relate it to Humoldt's 1821 conference!), the limits and potentialities of the linguistic turn are officially exposed: "the belief that language is the constitutive agent of human consciousness and the social production of meaning, and that our apprehension of the world, both past and present, arrives only through the lens of language's precoded perceptions" is the "semiotic challenge" that has been posed to historiography in the last decades. Spiegel analyzes Rorty's contribution, his progressive despondency with the war machine he had created, as well as assesses what she names as "the possible psychical roots of the linguistic turn," and thus finds arguments to justify Derrida's position as the unavoidable effect of his condition as the son of Frank-Algerian Jews and "the inescapable consciousness of the Holocaust" (SPIEGEL 2009).

To Spiegel, it would not be difficult to establish a parallel between the psychology of the linguistic turn and the basic principles of what she calls "poststructuralism: "the feeling of life as a trace, haunted by an absent presence; its sense of indeterminacy; a belief in the ultimate undecidability of language (its aporia, in Derrida's sense)"; in other words, the difficulty of speaking and representing the unutterable in the same perspective as Dominick La Capra.

The historian finally wonders where is history heading after the linguistic turn. Based on Nancy Partner, for whom history has entered a post-post-modern period, Spiegel remarks that "it is highly unlikely that we will return to 'quasiscientific realism, naïve empiricism, or any of the pre-postmodern assumptions that informed the writing of history'". It is also unlikely that most historians "will answer the call to 'sublime historical experience' recently issued by F. R. Ankersmit". What is likely, according to her, now following Michael Roth, is that the themes highlighted in the historiographical agenda will not leave issues such as "ethics, intensity, postcolonialism, empire, the sacred, cosmopolitanism, trauma and animals" aside (SPIEGEL 2009). What all these themes have in 
common is the attempt to reestablish a more direct and immediate connection with the past or some central aspect of experience that does not necessarily goes through the predominance of language.

Finally, from Derrida's deconstruction, Spiegel keeps the often-enigmatic formula of grasping and listening to the silences of history from fragmented narratives:

\begin{abstract}
We live in a moment of great cultural instability and uncertainty. As historians, we struggle to know the absent and the other, to affirm a right to words and to speech. Like Derrida, we are "trying to write the question: (what is) meaning to say?" Precisely what instruments we will deploy in the pursuit of our historical labors is not entirely clear. But I persist in believing that there is one thing that deconstruction has taught us, more powerfully than any other strategy of reading that I know of, and that is to listen to silence (SPIEGEL 2009).
\end{abstract}

Could not these silences, I ask, mean a shade or effect of our specter, now almost 40 years old? Or simply a possible way of reaffirming the ambience of indeterminacy of historical knowledge when related to the provocations of the linguistic turn ${ }^{14}$

\title{
The Specter Surrounds the Marxists
}

I have chosen to begin my analysis with what I call the "first effects" of the linguistic turn on Brazilian historiography. It would be hasty to speak of an "impact," a possibility of reception that seems to require not only a greater quantity of sociological data, but also a broader duration. ${ }^{15}$ These first deployments occur in a difficult if potentially rich moment in the political history of the country: the end of civil-military dictatorship. In Brazil, as in other countries, it has produced, simultaneously, theoretical disputes and breaches. Disputes of all types - ideological, epistemological, aesthetic, and others - were set in many research fields and areas, from the most established to those being formed, yielding disparate understandings or mere academic prejudices. If I were to choose an image to depict these disputes, that will be M. C. Escher's 1953 lithograph Relativity (Figure 1). ${ }^{16}$

\footnotetext{
${ }^{14}$ It is not my intension to place Spiegel in a context that is strange to her or an affiliation that is not claimed by her. In a 1992 article, she acted like a "mediator," recognizing both the belief in the reality of the past and the fact that history is a written discourse, that is, that language rebuilds the object (SPIEGEL 1992). For a more thorough analysis of Spiegel's position, see Alun Munslow's book (1997, p. 106-017), which, with high theoretical rigor, exposes the debate between empiricists, reconstructionists and deconstructionists (not in Derrida's sense, as the author explains, p. 2) backed by the discussion on the forms of objectivation of historical knowledge and its twin figures, among which the issue of relativism stands out.

${ }^{15}$ I thank Fernando Nicolazzi for drawing my attention to this very relevant distinction, not always realized or considered by historians.

${ }_{16}$ Using Escher's lithograph as a metaphor related to the linguistic turn is not an original idea. Elias Palti, in the prologue to the anthology of texts by Paul Rabinow, Stanley Fish, Dominick La Capra and Richard Rorty, already draws on it, even if with different aims and broader theoretical presuppositions and from the standpoint of a two-hundred-year-old crisis of "representation." Even then, I believe there are points of contact with what I am trying to establish (PALTI 1998).
} 


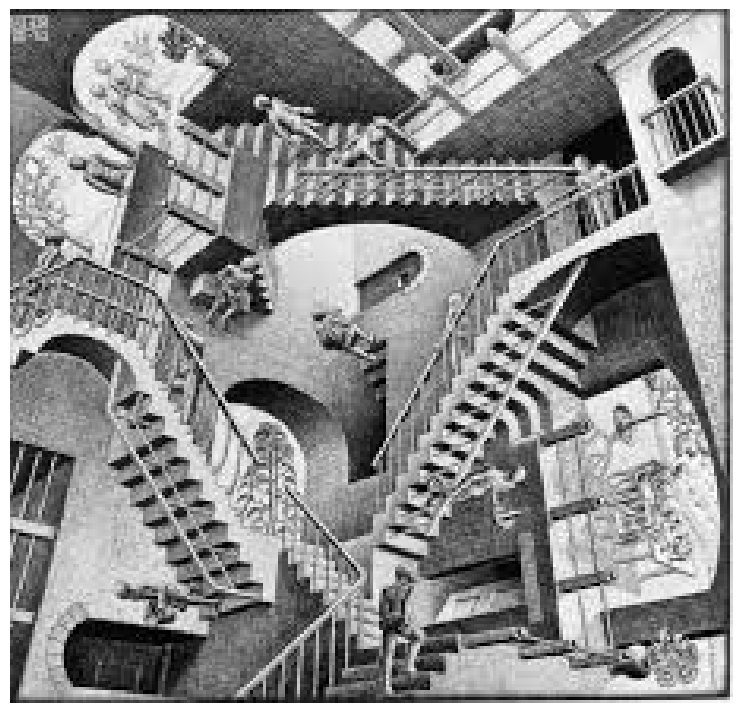

Figure 1 - M.C. Escher, Relativity, 1953.

In general, response came from France, with but a few foreigners such as Lawrence Stone and, later on, Carlo Ginzburg. Derrida's work was at this moment virtually ignored by historians (and apparently it is still so, with rare exceptions) against the already cited "Le discours de I'histoire," by Roland Barthes, also of 1967, which, counting little more than ten pages, had a greater "effect." Indeed, conflicts and differences overseas were virtually subsumed in a new and comprehensive identity: the "theory" of new history, more precisely the history of mentalities.

Marxist historians, representing the best established field and area, have revolted against the trend that was insinuating itself. In addition to denouncing the thematic and theoretical fragmentation, there was the risk that the unavoidable relativism resulting from abandoning "significant social totalities" would conduce to epistemological irrationality and political lethargy. Although there were more sophisticated answers, such as the one by Sérgio Paulo Rouanet, among historians, less bold, even if more impacting, analyses prevail (ROUANET 1987, p. 124-146).

Ciro Flamarion Cardoso in particular warned us about the dangers that those "radical distortions or inversions of perspectives" would mean to historiography. In his Ensaios Racionalistas (1998), "without concealing" his "radical opposition to a 'New History', which appeared" to him as "a reactionary trend disguised in novelty and boldness," he presents its risks and/or errors: "1. Valuing what is peripheral in relation to what is central; ${ }^{17} 2$. valuing not social reality, the actual conditions of existence, but its reverse - dreams, images, ideologies; ${ }^{18} 3$. technicism that values computer and other vanguard techniques conceals great methodological

\footnotetext{
17 "Madmen, outcasts, homosexuals, witches, and whores are preferred as objects of study (according, actually, to disposable fashions)" (CARDOSO 1988, p. 100) It is curious that Laura de Mello e Souza's relevant study, which claims to belong within the field of history of mentalities, is not cited here (SOUZA 1986).

18 "In a 'reading' that analyzes verbal or non verbal (e.g., iconography) discourse from the principle of a split between ideological and economical-social evolution, thematically, macabre dances, 'repressed drives of lust', sabbats, ghosts and obsessions are legion, and anachronism as a projection of current perceptions related to the society of nowadays (feminism, 'gay problem') into times when they are lacking in meaning and reality are frequent" (CARDOSO 1988, p. 100).
} 
poverty" (CARDOSO 1988, p. 94). ${ }^{19}$ In other words, New History has a powerful ideological function: although it is not an "open defense of capitalism," but a "far subtler form" of support, insofar as "once rationalism and especially Marxism are eliminated, that which remains, although it is not said, is capitalism - and a series of conceptions which are not troubling to it" (CARDOSO 1988, p. 101).

In this first approach, although Cardoso acknowledges the validity of some themes "which in many cases are pertinent and called for by the current moment" (CARDOSO 1988, p. 114) as long as they are properly dealt with, criticism is still very diffuse: a general attack on almost every current production which is not Marxist-oriented. For instance, there is no dialog between New History, post-structuralism or post-modernity, as it will soon be perceived, and even less a demonstration of what would be the irrationalism of these trends in terms of theory or philosophy of history. ${ }^{20}$

With this purpose, in 1989 Michel Zaidan Filho publishes A crise da Razão histórica, a collection of texts with the aim of understanding "the role of Marxism - as theory of history" and "the meaning of its current crisis" (ZAIDAN 1989, p. 15). Marx's thought, a product of Enlightenment and modern reason, is cornered by "new methodologies" marked by the "fragmentary, micrological, particular, fortuitous, imaginary, sex and other" whose result for "Brazilian culture" is the emergence of "a new surge of irrationalism" (ZAIDAN 1989, p. 16, 19). The philosophical matrix of this epistemological malaise is "some neo-nietzschianism" provoked mainly by the works of Michel Foucault and by "post-modern society" 470 (ZAIDAN 1989, p. 19-20). The irrationalist conception of history is founded on a "dereferentialization of reality, effected by the action of the media, by reducing everything to simulacrum, simulation, representation of reality" (ZAIDAN 1989, p. 21). In parallel, post-modernity generates a "de-substantialization of the subject - which directly affects, according to the author, the theory of history -, reduced to a mere cluster of hedonistic sensations, administered by consumer society" (ZAIDAN 1989, p. 22).

Like Ciro Cardoso, Zaidan Filho is concerned with how this trend will be received by Brazilian historiography and its relationship with the political context. Delayed in relation to developed capitalist countries, due to the transition from dictatorship to a more open regime, Brazilian historians would be easy preys of a debate that has its roots long ago in the United States and in Europe under the "modern and sophisticated cultural industry": "Thus, the anti-enlightenment, anti-intellectual, and ultimately anti-rationalist forms that the cultural debate in the 'New Republic' are taking are not surprising" (ZAIDAN 1989, p. 23).

As examples, he cites the production of academic theses and studies that invoke Foucault's "thought", that of "a certain Foucault, the post-structuralist one", clarifies the author. Actually, the only Brazilian historians that deserve to be mentioned in this chapter, and in two brief footnotes, are Nicolau Sevcenko,

19 "Sources are chosen arbitrarily, treated with no rigor, used with little judgment and reason" (CARDOSO 1988 , p. 100).

${ }^{20}$ In a previous work, aimed at students, published in 1981, Ciro F. Cardoso reveals his misgivings in relation to so called New History with critiques addressed exclusively to Paul Veyne (CARDOSO 1981, p. 10-11, 39). 
whose book Literatura como Missão (Literature as Mission), of 1983, would be a demonstration of the mistaken reception of Walter Benjamin, mainly of the "Benjaminian concept of criticism", and Edgar de Decca, who would have gone "too far in an orgiastic defense of the meaning, of unreason", in his O silêncio dos vencidos, published in 1981 (DECCA 1981; SEVCENKO 1983; ZAIDAN 1989, p. 25). ${ }^{21}$ The pre-notions, and a considerable dose of academic thoughtlessness, do not, however, prevent Zaidan Filho from acknowledging "one can no longer ignore the irrational and ideological limits of political or theoretical discourse" (ZAIDAN 1989, p. 25). The solution would not be in the abandonment of reason "as such", but in the construction of another rational paradigm-"communicative reason", as he posits (without citing Habermas!). ${ }^{22}$

In addition to that certain Foucault, Zaidan Filho highlights that Brazilian historiography was under the influence of myriad thematic novelties- "frequently with anachronistic projections of very current issues on a far past" (ZAIDAN 1989 p. 23, author's emphasis)-springing from the "Nouvelle histoire". He quotes nominally only one of these historians who provoke the "fascination for the glow of unusual, heterodox themes", in order to do "justice", since one should distinguish "authors such as Ginzburg or Vovelle and those like Philippe Ariès" (ZAIDAN 1989, p. 23-24).

To support his thesis, he uses the book Ensaios Racionalistas with one remark: "his approach [that of Ciro Cardoso] lacks, nevertheless, an articulate theory of the crisis of modernity. Therefore, the attachment to and reiteration of old presuppositions: dialectical materialism, the reflection theory, the theory of the modes of production etc." (ZAIDAN, 1989, p. 24, italics by the author). In any way, the reader ends up without understanding why to make such a distinction, that is, knowing the difference between the former two authors and Ariès. ${ }^{23}$ Indeed, the Italian historian seems to be a model for the new and correct historian, since he is capable of effecting the "analytical reconstruction of the difference between past and present, such as he did studying the mentality of a medieval miller", an enquiry wherein the author offers a "harsh and relevant critique to M. Foucault's structuralist 'irrationalism'"' (ZAIDAN 1989, p. 74).

Unlike Ciro Cardoso, Zaidan Filho is both a critic of orthodox Marxism and an interlocutor to "new" historians who do not assault modern reason. ${ }^{24}$ However,

\footnotetext{
${ }^{21}$ Both studies were presented originally as doctorate dissertations. Afterwards, in an article titled "Imaginário e História," (Imaginary and History), Zaidan Filho once again criticizes Sevcenko and de Decca, including historians Margareth Rago (RAGO 1985) and Maria Clementina Pereira Cunha (CUNHA 1987). The crime of these authors is the influence of Foucault and the "Nouvelle histoire", (ZAIDAN 1989, p. 39).

22 It should be said that he cites him in the following article (ZAIDAN 1989, p. 27).

${ }^{23}$ Philippe Ariès is cited again as an uncomfortable reference in Chapter 5 - The new look of the historian along with Paul Veyne (ZAIDAN 1989, p. 72, 74). On the other hand, Jacques LeGoff is spared for criticizing the "shredding of society" in certain investigations on daily life (ZAIDAN 1989, p. 73).

${ }^{24}$ Even though it is not my focus right now, it is important to remark that Ciro Cardoso, years after, in 1997, tries to counter this void in the introduction to a collective work organized jointly with Ronaldo Vainfas, where he summarizes the debate between two great paradigms: enlightenment and post-modernism. Whereas the first is characterized by the use of reason, the second is marked and crossed by "skeptical and ironic" stands, by "relativistic culturalism", by "relativistic hermeneutical method", by "subjectivism", "irrationalism", "mysticism", an "exclusive empire of relativism and microanalysis" (CARDOSO; VAINFAS 1997, p. 1-23). It should be highlighted, however, that the book's strength lies in not restricting the participation of one author or another due to their supposed position in relation to these two paradigms. In this vein, see Ronald Vainfas's careful conclusion named "Caminhos e descaminhos da história" (CARDOSO; VAINFAS 1997, p. 441-449). In 2012, these authors edited Novos domínios da história (CARDOSO; VAINFAS 2012). The
} 
his analysis does not clarify what exactly troubles him in theoretical, and even political, terms, and, finally, what is the great evil hiding behind what he calls relativism or irrationalism. ${ }^{25}$ Have we remained in a sort of epistemological limbo?

Carlos Fico and Ronald Polito, in a painstaking mapping of Brazilian historiography from 1980 to 1989, have diagnosed this lack of connection. The supposed crisis of reason and its counterparts falter due to their weak "links": "The understanding on what is the 'irrational' part of History is always very poorly explained." For them, the subjectivity inherent to certain themes, the history of daily life, for example, is not easily explained by "a scientific reason that supposes macrostructural determinations". On the other hand, this does not mean that daily events, thus subjected to subjective conditions, "are definitely thrown into a chaotic and unintelligible world of contingencies" (FICO; POLITO 1992, p. 168). ${ }^{26}$ In the lack of conceptual and methodological operators and in the "detachment to theory on the part of Brazilian historians", either Marxists or in other historiographical trends, the authors identify crucial factors for a debate pursued in such insufficient terms (FICO; POLITO 1992, p. 170-175). ${ }^{27}$

\section{Specter, Relativism, and Indetermination (II)}

A history of historiography regardful of intellectual movements of discontinuity would have to realize that, despite everything, there were attempts toward more refined and critical theoretical reflections on this new "gang of new ideas" (certainly not as new as those that crowded the times of Sílvio Romero). It is due to this analytical possibility that I believe that the impact of the linguistic turn was a gap as well, in the sense attributed by Hannah Arendt, that is, "an in-between period which sometimes inserts itself into historical time, when not only the later historians but the actors and witnesses... become aware of an interval in time which is altogether determined by things that are no longer and by things which are not yet" (ARENDT 1992, p. 35-36).

Since an exhaustive survey on the reception of the linguistic turn by Brazilian historiography is still lacking, only some seminal studies of the 1980s will be addressed without fixating or determining a start or an origin or attributing to these studies a status they do not claim to have nor have attributed to themselves; not out of fear of anachronism, but out of intellectual respect.

\footnotetext{
introduction, titled "História e conhecimento: uma abordagem epistemológica", by Ciro Cardoso, is focused on "the basic or principal modalities of epistemology of history," subdivided into three: reconstructionism (mainly "empiristic" conceptions of the 19th century), constructionism (Marxism, Weberianism, and the Annales); deconstructivism (basically exemplified by Hayden White and Paul Veyne) (CARDOSO; VAINFAS 2012, p. 1-19). Once again, Ronaldo Vainfas elegantly counteracts in the conclusion - "Doomed advancements, helpful returns" - relativizing some excessively general arguments by Ciro Cardoso (CARDOSO; VAINFAS, 2012, p. 319-335). In addition, it should be added that, in 2005, Ciro Cardoso once again invests against the "linguistic turn" and "deconstruction", based on a work by David Carr (1991), in which Hayden White and Hans Kellner are defined as historians that deny the "existence, outside, of a history that needs to be told" (CARDOSO 2005, p. 64-66).

${ }^{25}$ For a closer analysis, see Sílvia Petersen's "interrogations" (PETERSEN 1992a, p. 108-126).

${ }^{26}$ This reference may be applied to other citations in this paragraph. Within the same context, and specifically in relation to the history of daily life, Sílvia Petersen dedicates a series of articles to the theme, attempting to approach it in theoretical and methodological terms (PETERSEN 1992b, p. 108-126; 1993, p. 41-55; 1994, p. 112-25; 1995, p. 30-39).

27 In 1997, Carlos Fico still regretted the indifference of many historians in relation to theoretical reflection (FICO 2000, p. 27-40).
} 
From these consideration, I synthetically resume to Luiz Costa Lima's paper named "Clio em questão: a narrativa na escrita da história" presented at the "Colóquio narrativa: ficção e história", which took place in Rio de Janeiro in November 1987. In this work, Costa Lima brings together in a most unexpected way conceptions arising from Anglo-American narrativists, such as Hayden White, and from French historiography as well, their relationship with the anthropology of Lévi-Strauss and the work of Paul Ricœur (LIMA 1988, p. 63-89). ${ }^{28}$

Costa Lima's use of White's work interests me here. Without rejecting Metahistory in its entirety, Costa Lima's criticism is focused on two articles published by White in the first half of the 1980s. ${ }^{29}$ Discussing the distinction between historical and fictional narratives and the aim of prefaces in one or the other genre by W. Dray, whose analysis would have been undermined by the chosen example, Costa Lima is searching, in White's work, for an alternative that "had constituted the hypothesis that all narrative, from folk tale to the novel, presupposes a search for ordering from a socially configured rule" (LIMA 1988, p. 77).

Accordingly, the writing of historical annals during the Middle Ages, mentioned by White, would be a problem, but not necessarily an objection to the narrativist thesis. Costa Lima moves the case in order to present two "solutions": 1. Considering that narrative has no obstacle in Classical Antiquity, "we should say that the thesis has no universal reach since the ordering of beginning-middle-end does not apply to Medieval examples"; 2. On the other hand, if the idea of social rule is an indispensable element of narrative ordering, than Medieval annals would be excluded, by White's analysis, from the ambit of historical narrative. Linguistic links needed for the structure of a narration, established by a social center of power, would be lacking. Costa Lima points out that the absence of the State during the Middle Ages does not imply anomy: "Human community was organized there around a law, which, inscrutable, imposed the impossibility of explicative causal links to the events in the world" (LIMA 1988, p. 78). Then, on the one hand, Costa Lima agrees that historical narrative is evidently related to the political instance of a given society and, on the other, and for the same reason, he disagrees that Medieval annals and chronicles are out of the narrative scope due to the "absence of any awareness of a social center," as White seems to suggest (LIMA 1988, p. 77).

To Costa Lima, "White's position cannot be merely counted among those of the narrativists; it actually opens up a divergent path." Accordingly, "narrativists fail in seeing the writing of history as determined to provide nothing but information and, thus, in not suspecting of its proximity to literature". However, he sees in White, and this was not easy to see in the

\footnotetext{
${ }^{28}$ The German contribution for the discussion on the relationship between history and narrative was not, as explained by Costa Lima in a note, central, even though the importance of two books is remarked: one by K. Enlich (1980) on the narrative of daily life and mainly one organized by R. Koselleck and J. Rüsen on the theory of history (LIMA 1988, p. 68).

29 "The value of narrativity in the representation of reality" (Critical inquiry, 1980) and "The question of narrative in contemporary historical theory" (1984, History and theory), both reproduced in WHITE 1987.
} 
1980s (nor is it today), that "one should honestly add that White does not seek to establish an absolute identity" between history and literature. For him, "historical narrative is not concerned with fictional objects, but with real events, arranging them with the aid of fictional forms active within a culture" (LIMA 1988, p. 85). ${ }^{30}$

Nevertheless, he is not in agreement with some of White's premises (e.g., the analysis of Marx's The Eighteenth Brumaire of Louis Napoleon, which began in Metahistory). ${ }^{31}$ In spite of this disagreement, Costa Lima believes

it is undeniable that [White's] reflection is considerable for those interested in better specifying the statuses of history and fiction. Due to the pressure for a scientific history, historians in general have been neglectful of the role imagination plays in their work and, out of fear of moving away from 'objectivity', have wasted part of the wealth of their material (LIMA 1988, p. 85-86).

Once again, the specter that surrounds us reappears; however, coming from Costa Lima, it looks less frightening. ${ }^{32}$

Commenting on the text, Ricardo Benzaquen de Araújo focuses on the relationship between history and fiction. For such, he reconstructs Costa Lima's argument, including the works of Anglo-American narrativists, White, and Ricœur, confronting them with central aspects of Lawrence Sterne's hypotheses. Particularly in relation to Costa Lima's critique of White's opinions on the narrative potential of the Medieval annals, Benzaquen ascertains that it is not about privileging one political-social order instead of another, in this case "cosmo-teological", but affirming that the latter would not be able to bestow, "in the level of the very text", a "specific articulation of human events". Reversing Costa Lima's conclusion, Benzaquen argues that "perhaps it would be possible to point out that, precisely because of presupposing a religious, mysterious explanation, 'inaccessible to meek human reason' [in Costa Lima's words], the annals have moved away from the narrative model, at least from this written and modern narrative" (ARAÚJO 1988a, p. 102). In addition, the commenter draws our attention to the prudence needed in order not to naturalize the linking of the narrative mode of writing history - "its unique, contextual, non universal character" to a "social center" or "the world of nations", above all when one is speaking of the $19^{\text {th }}$ century, thus avoiding manipulating or instrumentalizing history (ARAÚJO 1988a, p. 102). ${ }^{33}$

\footnotetext{
${ }^{30}$ Reference to all citations in the paragraph.

31 Unfortunately, I will not be able to discuss the still relevant critique by Costa Lima to White's approach of Marx's The Eighteenth Brumaire. The dissidence concerns the theme of the "farce" and the constitution of the historical fact. I only highlight that it would also be interesting and possibly productive to consider the theme from the figure of imitation.

32 The analysis of the so called "Trilogy of control", published in the 1980 s as well as Costa Lima's clearing with the debate on history and fictional genres, published in 2006, would be important for a more thorough evaluation of the impact and importance of these issue; however, in practical terms, this is not possible in the space of one article (LIMA 2006; 2007).

33 "It [narrative] needs to be minimally qualified, especially as there is the risk of imagining the historical report as useful only for glorifying national states, as if it were merely a piece of propaganda or something similar" (ARAÚJO 1988a, p. 102-103).
} 
In relation to the debate on the return of the narrative, Benzaquen reflects that

many of the works involved in this revival end up, at least in part, distancing themselves from an absolute commitment with totality as a requirement that imposed on them the building of a coherent, exhaustive, and systematic image of the society they are studying (ARAÚJO 1988a, p. 108).

Therefore, the commenter follows:

it is not rare that their analyses give the impression that 'something' is missing, creating a sense of something unfinished and undetermined that may draw this new narrative close to a certain concept of essay. [...] In case these speculations are confirmed, the revival of narrative will have a broader reach and a broader meaning than initially supposed (ARAÚJO 1988a, p. 108-109, italics added).

The return to narrative may be responsible for "a certain change in the ethos of the historian," since historians usually searching for truth, facts and structures, have always leaned toward "transparency and clarity, despising the possibilities offered by controversy, confrontation, by an ongoing problematization" (ARAÚJO 1988a, p. 109). Finally, this way, "the space reserved to irony" would be broadened "in order for it to cohabit with a certain skepticism" (ARAújO 1988a, p. 109). Now, the twin figure of the specter, under a controlled effect, seems to be going toward a kind of neopyrrhonism as an alternative to historical reflection. It is worth remembering the title of Benzaquen's commentary: "The souls of history!"34

One year after the event in Rio de Janeiro, in 1988, in the first volume of the journal Estudos Históricos (Historical Studies), in a dossier meaningfully titled "Caminhos da Historiografia" (Pathways of historiography), Manoel Salgado Guimarães and Ricardo Benzaquen Araújo himself published articles that would become an inspiration for the history of historiography and for reflection, in spite of them, of the effects of the linguistic turn among us (GUIMARÃES 1988; ARAÚJO 1988b). Even though a more thorough analysis is not possible right now, ${ }^{35}$ I offer one comment on each of them. The first article, "Nação e Civilização nos Trópicos: O Instituto Histórico e Geográfico Brasileiro e o Projeto de uma História Nacional", by Manoel Salgado Guimarães is, as we know, a summary of his thesis, presented a year earlier at the University of Berlin. The writing of history is studied from presuppositions that involve Koselleck's historical

\footnotetext{
${ }^{34}$ At the 2013 debate at PUC-Rio, I had the opportunity to ask Ricardo Benzaquen Araújo what was the reason for the title. He answered: "To maintain the plurality of the concept of history". I was more than satisfied! ${ }^{35}$ It is probable that the great Brazilian absences in this analysis are Arno Wehling and Afonso Carlos Marques dos Santos, whose first writings are found within this context. For different reasons, it appears to me that both point to a type of reception other than the linguistic turn. Whereas the first participates in a broader movement in historiographical culture in which the philosophy of history is a relevant factor in defining disciplinary and scientific codes (WEHLING 1994), the second is, although I cannot be sure of this point of view, closer to what we could call, in the lack of a more qualified definition, an erudite-commitment. Hence the relevance of authors such as Cornelius Castoriadis, Michel Foucault and Paul Veyne in their research, far greater than that of Hayden White, for instance (SANTOS 2007). I thank Valdei Lopes de Araujo for indicating this omission to me. By the way, his article - "O Século XIX no Contexto da Redemocratização Brasileira: A Escrita da História Oitocentista, Balanços e Perspectivas" - is, in this sense, revealing, even though I am not sure he agrees with my line of thought (ARAUJO 2012).
} 
semantics sustained by the reading of Michel de Certeau and Foucault without, however, artificially unifying them, but using them as theoretical instruments to conceive of historiographical narrative. It is not a copy of foreign theoretical models, but a dialog with other historiographical cultures.

On its turn, Benzaquen's text, "Ronda Noturna: Narrativa, Crítica e Verdade em Capistrano de Abreu", explicitly claims the contribution of Hayden White (as well as Costa Lima, Koselleck, Momigliano, Ricœur, Benjamin) and hence the background question that emerges is that of historical objectivity and its modes:

The question of objectivity is still open to discussion, that is, we still have to ask how and why the ideal of an absolutely realist and impartial discipline has become so prestigious among those who work with the modern conception of history, who often can hardly perceive the 'informed' character of formulations that, almost as a "sorcerer's apprentices", they are used to employ (ARAÚJO 1988b, p. 53).

And in a footnote to this passage (n. 15) he explains:

If every now and then sorcerer's apprentices may get the formula to transform plumb into gold right, I believe it is worth pointing out that only very recently, after "the school of the Annals", and a certain articulation of historiography with the sociological tradition, on the one hand, and with literary theory, on the other, one can find historians willing to discuss the reach and depth of their presuppositions more broadly. On this "historiographical mutation", for a first approach, one should look for the works of Furet, 1982, and White, 1984 (ARAÚJO 1988b, p. 53).

Thus, there was an "impact" (one should be watchful of the analytical and methodological limitations previously mentioned) of the linguistic turn in Brazil. More studies should be undertaken to assess its real dimensions and consequences. It is not enough to denounce it as relativistic, irrational or skeptic, nor to deny the importance of the forms of objectivity or objectivation of historical knowledge, among which the very idea of truth, whose endurance, we know, predates the last 40 years. ${ }^{36}$

\section{Cartesian (in)determination and (un)certainties}

Without being overly prescriptive, would it not be interesting if we put ourselves in the place of that intellectual Hamlet? Who or what would be a Brazilian Hamlet? A person? Many? A corporation? An epistemological configuration? How can we meditate on the life and death of truths and ghosts originated in our controversies? It is difficult to answer. Nevertheless, I would like to evoke two contemporary poets and try to bring us near the historical atmosphere marked by the instability that, at the same time, frightens and

\footnotetext{
36 "One will hardly find a historian who does not aim at objectivity patterns for his or her knowledge. Today, however, there are many options of understanding what objectivity is or what levels of objectivity are possible to reach in each case. These are complex theoretical problems, greater than the old discussions on the possibility or impossibility of a historical or scientific knowledge. Not facing it is delaying the incorporation of discussions aroused by the discoveries on indeterminism, on relativity and on observable discrepancies in many levels of reality even more" (FICO 1994, p. 115).
} 
incites, and that may give us some hints, in addition to bringing us near an undisguised Aristotelian desire found in Hayden White's work of uniting poetry and history (WHITE 2010a, p. XI).

Both are paradoxically related, not to Aristotle, but to Descartes. First, we can imagine Descartes in Brazil with the entourage of Maurice of Nassau in Recife in the $17^{\text {th }}$ century. In 1966, Paulo Leminski had, while teaching a history class, this exact insight. A Descartes - Renatus Cartesius - in the tropics! Catatau, the work that deals with this impossibility, was independently published in 1975 during military rule: "Catatau is the failure of white Cartesian logic in the hot weather" (LEMINSKI 1989, p. 208). ${ }^{37}$ Would it be a concretist metaphor of its present time? How to be clear and distinct among obtuse generals? However, nothing allows, in principle, this interpretation. Except perhaps time elapsed and the strong tendency that results from it, to which I am not entirely immune, that leads historians, wittingly or not, to somehow associate each and every artistic experience, avant-garde or countercultural, to grand political history. As if discontinuity was an obstacle to understanding and not one of its forms of expression. Thus, if here and today, as there and yesterday, Catatau appears as an example of the instability of the word, of the text that disturbs, of uncertainty that dismantles intellectual order, then it would not be an exaggeration to think of this "idea-novel", in the author's definition, as a kind of aesthetic manifestation that symbolizes the indeterminacy that I have been searching as pointing to possibilities of thinking the history of historiography in this context of the linguistic turn: "Logic is not clean, as Europe suggests, since Aristotle. Their logic, here, is a farce, an impossibility". Catatau not only wants to overcome this logic, but also "to place the bases of a new logic". It wants to be an interval of sorts between "the eternal inadequacy of the established instruments in face of the emergence of unheard of realities" (LEMINSKI 1989, p. 211). ${ }^{38}$

Mr. Cogito, on the other hand, is a more common person, a bit like Robert Musil's Ulrich, a little less contemplative perhaps, who, as years go by, converts day-to-day experience into clear and distinct questions about existence to be consistent with the Cartesian premise that names him. The character of numerous poems by the Polish poet Zbigniew Herbert, Mr. Cogito appeared probably in 1974. In one of these poems, significantly named Mr. Cogito on the Need for Precision, he claims: ${ }^{39}$

"A specter is haunting

the map of history

the specter of indeterminacy

how many Greeks perished at Troy

- we don't know" (HERBERT 2007, p. 404-408).40

\footnotetext{
${ }^{37}$ I warmly thank Professor Henrique Estrada for reminding me of Catatau's relevance to my argument.

38 This reference can be applied also to the two previous citations.

${ }^{39}$ I thank Professor Paulo Faria, my colleague in the Department of Philosophy at UFRGS, who, years ago, drew my attention to the work of Zbigniew Herbert.

${ }^{40}$ A coincidence: Troy also haunts Leminski's Catatau: "I remember the map, in this map Troy is missing, but no one is missing Troy. [...] Why this fear of saying Troy, story, Destroya? [...] I pledge a piecework, the strait bushwhack, introit in Troy" (LEMINSKI 1989, p. 50, 63, 95). Troy's seeming meaninglessness does not conceal, however, the importance of the presence of game in historical indeterminacy.
} 


\section{Bibliographic References}

ANKERSMIT, Frank. The linguistic turn: literary theory and historical theory. In: Historical representation. Stanford: Stanford University Press, 2001.

ARAÚJO, Ricardo Benzaquen de. As almas da história - Cometário. In: RIEDEL, Dirce Côrtes (org.). Narrativa, ficção \& história. Rio de Janeiro: Imago, 1988a, p. 90-111.

. Ronda noturna: narrativa, crítica e verdade em Capistrano de Abreu. Estudos históricos, n. 1, p. 28-54, 1988b.

ARAUJO, Valdei Lopes de. O século XIX no contexto da redemocratização brasileira: a escrita da história oitocentista, balanços e perspectivas. In: OLIVEIRA, Maria da Glória de; ARAUJO, Valdei Lopes de. (orgs.) Disputas pelo passado: história e historiadores no Império do Brasil. Ouro Preto: Edufop/PPGHIST, 2012.

ARENDT, Hannah. Entre o passado e o futuro. São Paulo: Perspectiva, 1992. BARTHES, Roland. Le discours de I'histoire. In: Bruissement de la langue. Paris: Seuil, 1984, p. 163-177.

CALDAS, Pedro Spinola Pereira. Para além do giro-linguístico: uma abordagem existencialista da obra de Hayden White. História da historiografia, $\mathrm{n}$. 11, p. 272-278, 2013.

CAMARGO, Aspásia. Entrevista François Furet concedida a Aspásia Camargo. In: OLIVEIRA, Lúcia Lippi; FERREIRA, Marieta de Moraes; CASTRO, Celso. Conversando com... Rio de Janeiro: Ed. da FGV, 2003.

CARDOSO, Ciro Flamarion. Uma introdução à história. São Paulo: Brasiliense, 1981.

. Uma "Nova História"? In: . Ensaios racionalistas. Campus: Rio de Janeiro, 1988.

. Um historiador fala de teoria e metodologia. Ensaios. Bauru: Edusc, 2005.

; VAINFAS, Ronaldo (orgs.). Domínios da história: ensaios de teoria e metodologia. Rio de Janeiro: Campus, 1997.

; . (orgs.). Novos domínios da História. Rio de Janeiro: Campus, 2012.

CARR, David. Time, narrative and history. Blooming: Indiana University Press, 1991.

CERTEAU, Michel de. Une épistémologie de transition: Paul Veyne. Annales, $\mathrm{n}$. 6, p. 1317-1327, 1972.

. L'absent de I'histoire. Paris : Maison Mame, 1973.

. L'écriture de I'histoire. Paris: Gallimard, 1975. 
. Histoire et psychanalyse entre science et fiction. Paris : Gallimard, 1987.

CUNHA, Maria Clementina Pereira. O espelho do mundo: Juquery, a história de um asilo. Rio de Janeiro: Paz e Terra, 1987.

DANTO, Arthur. Analytical philosophy of Science. Cambridge: Cambridge University Press, 1965.

DECCA, Edgar de. O silêncio dos vencidos. São Paulo: Brasiliense, 1981.

DELACROIX, Christian. Linguistic turn. In : DELACROIX, C. ; DOSSE, F.; GARCIA, P.; OFFENSTADT, N. Historiographies, I. Concepts et débats. Paris: Gallimard, 2010, p. 476-490.

DERRIDA, Jacques. De la grammatologie. Paris: Les Éditions de Minuit, 1967.

. Espectros de Marx. Rio de Janeiro: Relume-Dumará, 1994.

DRAY, William. On the Nature and Role of Narrative in Historiography. History and theory, v. 10, n. 2, p. 153-171, 1971.

DOSSE, François. L'histoire en miettes: des "Annales" à la "nouvelle histoire". Paris: Gallimard, 1987.

FICO, Carlos. Alguns impasses da produção historiográfica recente no Brasil. Anos 90, n. 2, p. 111-126, maio 1994.

Algumas anotações sobre historiografia, teoria e método no Brasil dos anos 1990. In: GUAZZELLI, Cesar A. B. et alii (orgs.). Questões de

teoria e metodologia da história. Porto Alegre: Ed. da Universidade/ UFRGS, 2000, p. 27-40.

; POLITO, R. A história no Brasil (1980-1989): elementos para uma avaliação historiográfica. V. 1. Ouro Preto: UFOP, 1992.

FURET, François. L'atelier de I'histoire. Paris: Flammarion, 1982.

GUIMARÃES, Manoel Salgado. Nação e Civilização nos Trópicos: o Instituto Histórico e Geográfico Brasileiro e o projeto de uma História Nacional.

Estudos Históricos, n. 1, p. 5-27, 1988.

GINZBURG, Carlo. Just one Witness. In: FRIEDLANDER, Saul (ed.). Probing the

limits of representation: nazism and the "final solution". Cambridge: Harvard University Press, 1992, p. 82-96.

Provas e possibilidades à margem de "Il ritorno de Matin Guerre", de Natalie Zemon Davis. In: A micro-história e outros ensaios. Lisboa: Difel, 1989, p. 178-220. . Montrer et citer. La vérité de l'histoire. Le Débat, n. 56, p. 44-45, 1989. Le juge et I'historien. Lagrasse: Verdier, 1997.

HARTOG, François. Régimes d'historicité, présentisme et expérience du temps. Paris: Seuil, 2003. 
. Le regard éloigné: Lévi-Strauss et I'histoire. In: Évidence de

I'histoire: ce que voient les historiens. Paris : Éd. de I'EHESS, 2005, p. 175-189.

Croire en I'histoire. Paris: Flammarion, 2013.

HERBERT, Zbigniew. The collected poems (1956-1998). New York: HarperCollins Publishers, 2007.

KOSELLECK, Reinhart. Introduction to Hayden White's Tropics of discourse. In: . The practice of conceptual history: timing history, spacing concepts. Stanford: Stanford University Press, 2002.

LA CAPRA, Dominick; KAPLAN, Steven (eds.). Modern European intellectual history: reappraisals \& new perspectives. London: Cornell University Press, 1982.

LIMA, Luiz Costa. Clio em questão: a narrativa na escrita da história. In: RIEDEL, Dirce Côrtes (org.). Narrativa, ficção \& história. Rio de Janeiro: Imago, 1988, p. 63-89.

. História. Ficção. Literatura. São Paulo: Companhia das Letras, 2006.

. Trilogia do controle: o controle do imaginário. Sociedade e discurso ficcional. O fingidor e o censor. Rio de Janeiro: Ed. Topbooks, 2007.

MINK, Louis. The autonomy of historical understanding. History and theory, v. 5, n. 1, p. 24-47, 1966.

History and fiction as modes of comprenhension (1970). In: COHEN, Ralph (ed.). New directions in literary history. London: Routledge \& Kegan Paul, 1974, p. 107-124.

MUNSLOW, Alun. Deconstructing history. London and New York: Routledge, 1997.

. The future of history. New York : Palgrave MacMillan, 2010.

NOIRIEL, Gérard. Sur la "crise" de I'histoire. Paris: Belin, 1996.

NORA, Pierre; LE GOFF, Jacques. (dir.). Histoire. T. 1 - Nouveaux problèmes ; $t$. 2 - Nouvelles approches ; t. 3 - Nouveaux objets. Paris: Gallimard, 1974.

PALTI, Elias José. "Giro lingüístico" e historia intelectual. Buenos Aires: Universidad Nacional de Quilmes, 1998.

PAUL, Herman. Hayden White: the historical imagination. Cambridge: Polity Press, 2011.

PETERSEN, Sílvia. Algumas interrogações sobre as tendências recentes da historiografia brasileira: a emergência do novo e a crítica ao racionalismo. Revista de história, v. 3, n. 1, p. 108-126, 1992a.

- Dilemas e desafios da historiografia brasileira: a temática da vida cotidiana. História e perspectivas, v. 6, p. 24-44, 1992b. 
. Michel Maffesoli: um teórico da vida cotidiana. Biblos, Rio Grande, v. 5, 1993, p. 41-55.

- A renovação da historiografia e a temática da vida cotidiana: desfazendo alguns equívocos. In: $\mathrm{MAUCH}$, Claudia (org.) Porto Alegre na virada do século XIX: cultura e sociedade. Porto Alegre: Editora da Universidade/ UFRGS, 1994, p. 112-25.

. O cotidiano como objeto teórico ou o impasse entre ciência e senso comum no conhecimento da vida cotidiana. MESQUITA, Zilá; BRANDÃO, Carlos R. (orgs.). Territórios do cotidiano: uma introdução a novos olhares e experiências. Porto Alegre: Ed. da Universidade da UFRGS/ EDUNISC, 1995, p. 30-39.

PIRES, Francisco Murari. Indagações sobre um método acima de qualquer suspeita. História da Historiografia, n. 13, p. 24-44, 2013.

POPKIN, Richard. The history of skepticism: From Savonarola to Bayle. Oxford: Oxford University Press, 2003.

RAGO, Margareth. Do cabaré ao lar. Rio de Janeiro: Paz e Terra, 1985.

ROBIN, Régine. Histoire et linguistique. Paris: Armand Colin, 1973.

RORTY, Richard. The linguistic turn: essays in Philosophical Method. Chicago, London: University of Chicago Press, 1967.

RICFUUR, Paul. Temps et récit. Tome I: L'intrigue et le récit historique. Paris: Éd. Seuil, 1983.

Temps et récit. Tome III: Les temps raconté. Paris: Éd. Seuil, 1985.

ROUANET, Sérgio Paulo. O novo irracionalismo brasileiro. In: As razões do Iluminismo. São Paulo: Companhia das Letras, 1987, p. 124-146.

SANTOS, Afonso Carlos Marques. A invenção do Brasil: ensaios de história e cultura. Rio de Janeiro: Editora da UFRJ, 2007.

SEARLE, John. Pour réitérer les différences, réponse à Derrida. Paris: L'éclat, 1991.

SEVCENKO, Nicolau. Literatura como missão: tensões sociais e criação cultural na Primeira República. São Paulo: Brasiliense, 1983.

SKINNER, Quentin (ed.). The return of grand theory to the human sciences. Cambridge: Cambridge University Press, 1985.

SOUZA, Laura Melo de. O diabo e a Terra de Santa Cruz: feitiçaria e religiosidade popular no Brasil colonial. São Paulo: Companhia das Letras, 1986.

SPIEGEL, Gabrielle. History and post-modernism. Past and present, n. 135, p. 189-208, 1992.

. The task of the historian. Presidential address delivered at the 123rd annual meeting of the American Historical Association, held in New York 
City in 2009. Disponível em: http://www.historians.org/about-aha-andmembership/aha-history-and-archives/presidential-addresses/gabriellem-spiegel. Acesso em: 7 ago. 2014.

STONE, Laurence. The revival of narrative. Reflections on a new old history. Past and present, n. 85, p. 3-24, 1979.

VALÉRY, Paul. Essais quasi politiques. In: Cuvres. Paris: Gallimard, 1957. (Bibl. De la Pléiade, t. I).

VANN, Richard T. Turning Linguistic: History and theory and History and theory, 1960-1975 In: ANKERSMIT, Frank; KELLNER, Hans (eds.). A new philosophy of history. London: Reaktion Books, 1995, p. 40-69.

. The Reception of Hayden White. History and theory, v. 37, n. 2, p. 143-161, 1998.

VEYNE, Paul. Comment on écrit I'histoire: essais d'épistémologie. Paris: Seuil, 1971.

WEHLING, Arno. A invenção da história: estudos sobre o historicismo. Rio de Janeiro: Ed. Central; Niterói: Ed. UFF, 1994.

WHITE, Hayden. The Greco-Roman tradition. New York: Harper \& Row, 1973. . The politics of historical interpretation: discipline and de-sublimation. In: The content of form: narrative discourse and historical

482 representation. Baltimore and London: The Johns Hopkins University Press, 1987.

. Historical emplotment and the problem of truth. In: FRIEDLANDER, Saul (ed.). Probing the limits of representation: nazism and the "final solution". Cambridge: Harvard University Press, 1992, p. 37-53.

. Trópicos do discurso: ensaios sobre a crítica da cultura. São Paulo: Edusp, 1994.

. The fiction of narrative: essays on history, literature and theory (1957-2007). Edited and with an introduction by Robert Doran. Baltimore: The Johns Hopkins University Press, 2010a.

Ficción histórica, historia ficcional y realidad histórica. Introducción de Verônica Tozzi. Buenos Aires: Prometeu Libros, 2010b.

ZAIDAN FILHO, Michel. A crise da razão histórica. Campinas: Papirus, 1989. 